\title{
Visualisasi Perubahan Volume Dan Elevasi Permukaan Lumpur Dengan Citra Satelit Resolusi Tinggi Temporal Untuk Monitoring Lumpur Sidoarjo
}

\author{
Bagas Tri Widodo dan Teguh Hariyanto \\ Jurusan Teknik Geomatika, Fakultas Teknik Sipil dan Perencanaan, Institut Teknologi Sepuluh Nopember (ITS) \\ Jl. Arief Rahman Hakim, Surabaya 60111 Indonesia \\ e-mail:teguh_hr@geodesy.its.ac.id
}

\begin{abstract}
Abstrak - Sejak awal terjadinya bencana lumpur Sidoarjo pada 29 Mei 2006 silam, telah terjadi lebih dari 10 kali jebolan tanggul penahan lumpur. Yang terakhir terjadi pada akhir tahun 2014 lalu, mengakibatkan rumah warga yang berada di Desa Gempolsari, Kecamatan Tanggulangin, terendam lumpur. Untuk mencegah hal yang sama terulang kembali, maka perlu dilakukan monitoring untuk mengetahui pola persebaran lumpur dan elevasinya yang berada di dalam tanggul penahan. Dengan menggunakan citra satelit resolusi tinggi WorldView-2 bulan Agustus 2014 dan Juli 2015, maka tutupan lumpur dapat diklasifikasikan menjadi 4 kelas berbeda, yaotu Air Berlumpur, Lumpur Basah, Lumpur Mulai Mengering, dan Lumpur Kering. Menurut hasil pengolahan data observasi lapangan menggunakan GPS geodetik metode kinematik, diketahui bahwa volume total lumpur di dalam tanggul utama pada bulan Maret 2014 adalah 44.039.123,365 $\mathrm{m}^{3}$, dan bulan Juli 2015 sebesar 47.646.879,058 $\mathrm{m}^{3}$. Berdasarkan hasil pemodelan 3 dimensi permukaan lumpur, aliran lumpur pada bulan Maret 2014 cenderung mengarah ke utara. Sedangkan pada bulan Juli 2015 aliran lumpur lebih terkonsentrasi di dekat pusat semburan, membuat tanah bagian bawah mengalami sledding dan penurunan. Dengan demikian, permukaan lumpur menjadi terlihat seperti kaldera atau fitur kawah gunung lumpur. Dan sampai dengan bulan Juli 2015, tutupan lumpur didominasi oleh klasifikasi Lumpur Kering.
\end{abstract}

Kata Kunci-Lumpur Sidoarjo, Elevasi Lumpur, Volume Lumpur, Model 3 Dimensi.

\section{PENDAHULUAN}

$\mathrm{B}$ ENCANA lumpur panas Sidoarjo, juga dikenal dengan sebutan Lumpur Lapindo atau Lumpur Sidoarjo (Lusi), adalah peristiwa menyemburnya lumpur panas di lokasi pengeboran Lapindo Brantas Inc. di Dusun Balongnongo, Desa Renokenongo, Kecamatan Porong, Kabupaten Sidoarjo, Jawa Timur, Indonesia, sejak tanggal 29 Mei 2006 [2]. Sejak awal terjadinya bencana ini, telah terjadi lebih dari 10 kali jebolan tanggul penahan lumpur. Yang terakhir terjadi pada tanggal akhir tahun 2014 lalu, mengakibatkan rumah warga yang berada di Desa Gempolsari, Kecamatan Tanggulangin, terendam lumpur. Sebelumnya, pada tanggaul 27 April 2011 telah terjadi jebolan tanggul di sisi utara, tepatnya di Desa Kedungbendo, Kecamatan Tanggulangin. Tanggul di Desa Kedungbendo jebol sepanjang 200 meter, mengakibatkan kawasan pemukiman yang padat penduduk tersebut sepenuhnya tenggelam [3].
Badan Penanggulangan Lumpur Sidoarjo (BPLS) adalah sebuah lembaga yang dibentuk dalam upaya menanggulangi semburan dan luapan lumpur, masalah sosial dan infrastruktur di sekitar kawasan area terdampak, dengan memperhatikan risiko lingkungan yang terkecil. Terkait dengan fungsi dari Badan Penanggulangan Lumpur Sidoarjo dalam menangani semburan lumpur, kemajuan teknologi Penginderaan Jauh dapat dimanfaatkan dalam proses monitoring dan evaluasi bencana yang ada.

Penginderaan jauh dapat dimanfaatkan untuk memperkirakan volume semburan lumpur dengan citra satelit. Terlebih, teknologi penginderaan jauh juga dapat dipadukan dengan data observasi langsung di atas permukaan lumpur. Hal ini dilakukan sebagai upaya untuk mengetahui kecenderungan persebaran arah aliran lumpur. Nantinya, visualisasi model tiga dimensi permukaan lumpur dari tahun ke tahun juga dilakukan untuk menggambarkan perubahan elevasi yang telah terjadi. Visualisasi tersebut dapat bermanfaat bagi pihak BAPEL BPLS, selaku badan yang menangani masalah lumpur Sidoarjo untuk melihat perubahan elevasi permukaan lumpur dari berbagai arah pandang secara dinamis.

Dengan adanya penelitian ini, diharapkan dapat membantu pihak BAPEL BPLS (Badan Pelaksana Badan Penanggulangan Lumpur Sidoarjo) dalam hal monitoring elevasi permukaan lumpur beserta kecenderungan arah aliran lumpur yang berada di dalam tanggul penahan. Selain itu, pemodelan 3 dimensi permukaan lumpur diharapkan dapat menjadi data pendukung bagi pihak-pihak berwenang untuk melakukan penanganan bencana lumpur yang telah terjadi sejak 10 tahun silam.

\section{II.METODOLOGI PENELITIAN}

\section{A. Lokasi Penelitian}

Lokasi penelitian dari tugas akhir ini adalah kawasan yang berada di dalam area terdampak lumpur panas, di Kabupaten Sidoarjo, Jawa Timur. Kawasan area terdampak lumpur Sidoarjo ini secara geografis terletak di antara $7^{\circ} 30^{\prime} 40^{\prime \prime}$ $7^{\circ} 32^{\prime} 31^{\prime \prime}$ LS dan $112^{\circ} 42^{\prime} 28^{\prime \prime}$ - 112 $43^{\prime} 6^{\prime \prime}$ BT. 3 kecamatan terdampak lumpur sidoarjo ini, antara lain Kecamatan Tanggulangin, Porong, dan Jabon. 


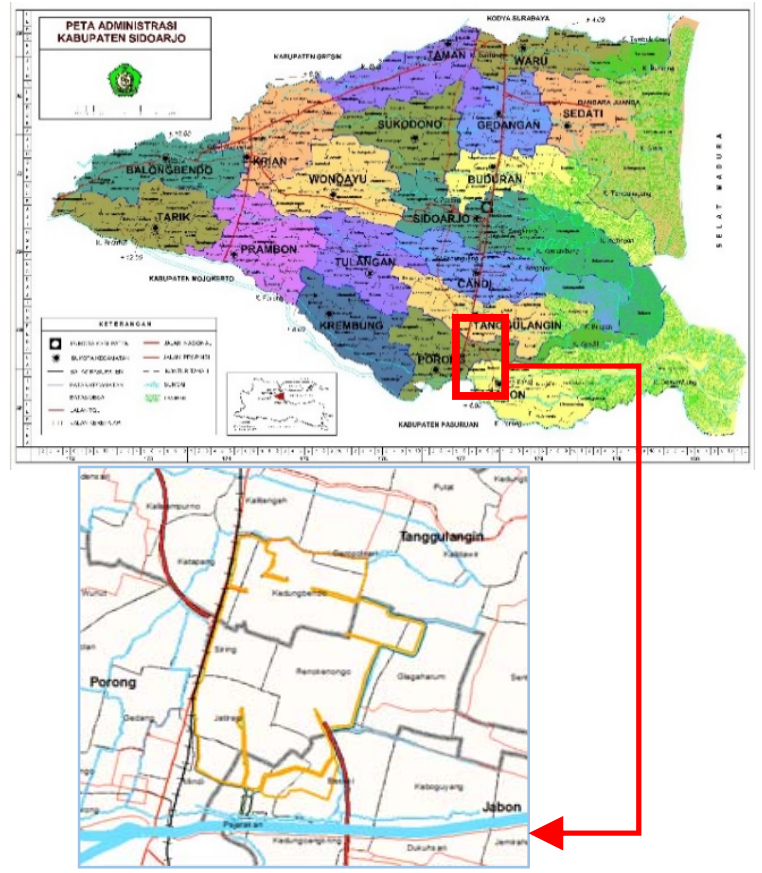

Gambar 1. Lokasi Penelitian.

(sumber : google.com dan dokumen Badan Penanggulangan Lumpur Sidoarjo)

\section{B. Metodologi Penelitian}

Tahapan yang akan dilaksanakan dalam penelitian tugas akhir ini adalah seperti pada diagram alir berikut ini:

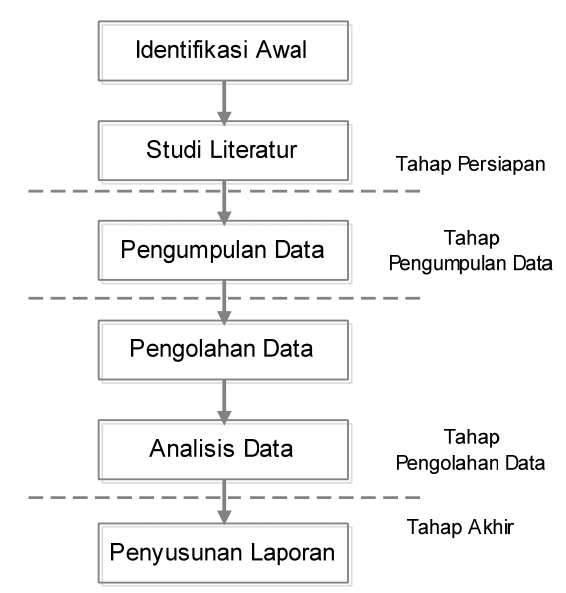

Gambar 2. Diagram alir tahapan penelitian.

Berikut adalah penjelasan diagram alir metode penelitian:

1) Tahap Persiapan

Pada tahap ini, kegiatan-kegiatan yang dilakukan adalah:

\section{a. Identifikasi Awal}

Identifikasi awal, bertujuan untuk mengidentifikasi permasalahan. Adapaun permasalahan dalam penelitian ini adalah bagaimanakah perubahan yang terjadi pada volume lumpur dan elevasinya di dalam tanggul penahan pada tahun 2014-2015 menggunakan metode penginderaan jauh dengan citra satelit resolusi tinggi, serta seperti apa kecenderungan persebaran arah semburan lumpur yang terjadi jika diperhatikan dari visualisasi 3 dimensinya. b. Studi Literatur

Bertujuan untuk mendapatkan referensi yang berhubungan dengan perhitungan volume tutupan lumpur, dan cara klasifikasi tutupan lumpur menggunakan citra satelit Worldview-2. Kemudian mencari literatur tentang pembuatan visualisasi 3 dimensi dari elevasi lumpur di daam tanggul penahan utama, dan metode pengumpulan data di lapangan. Semua literatur dicari berdasarkan literatur yang mendukung, baik dari buku, jurnal/paper penelitian sebelumnya, makalah ilmiah, internet, dan lain sebagainya.

\section{2) Tahap Pengumpulan Data}

Pengumpulan data dilakukan untuk mencari data-data yang menjadi pokok bahasan dalam penelitian tugas akhir ini. Data tersebut dapat berupa data angka tabular maupun grafis yang dapat menunjang proses penelitian ini. Adapun data yang digunakan dalam penelitian ini, antara lain berupa data citra satelit Worldview-2 tahun 2014-2015 di sekitar kawasan area terdampak lumpur Sidoarjo, dan data koordinat permukaan lumpur di dalam tanggul penahan, yang diperoleh dari observasi GPS Kinematik di lapangan. Pengukuran GPS Metode Kinematik dilakukan ketika objek/titik yang akan diukur bergerak, dan alat receiver pun bergerak [1]. Metode ini dipilih karena sifat permukaan lumpur sangat dinamis, sehingga lebih cocok dengan kondisi medan tersebut.

\section{3) Tahap Pengolahan Data}

Adapun alur dari tahap pengolahan data pada penelitian tugas akhir ini sebagai berikut:

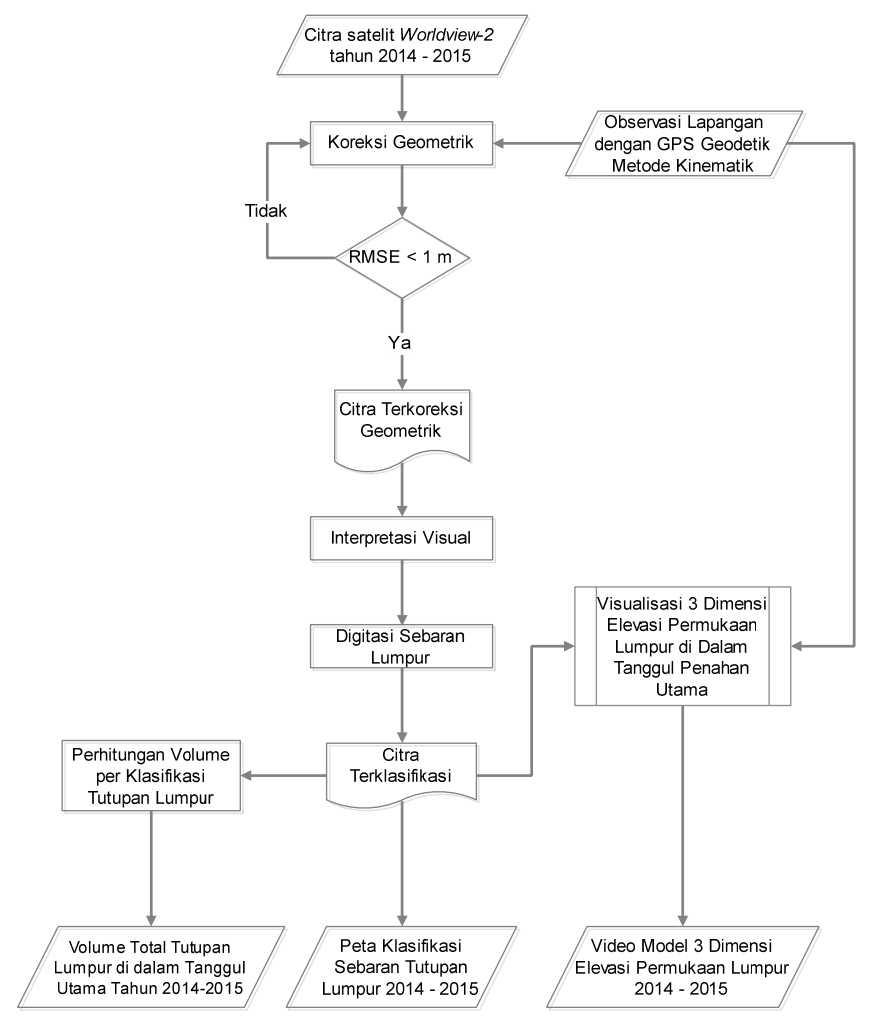

Gambar 3. Diagram alir proses pengolahan data.

Berikut adalah penjelasan diagram alir tahap pengolahan data: 
a. Pertama, adalah melakukan koreksi geometrik pada citra satelit resolusi tinggi tahun 2014 hingga 2015 untuk mereduksi kesalahan geometrik, dan akan dihasilkan citra terkoreksi geometrik. Koreksi geometrik ini melibatkan data observasi lapangan menggunakan GPS Geodetik sebagai acuan. Secara umum, formula untuk menghitung besarnya nilai RMS Error dalam bidang dua dimensional adalah sebagai berikut: [5]

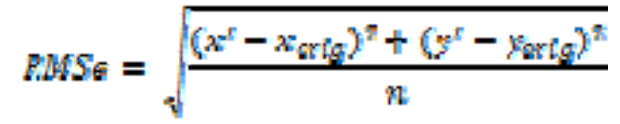

dimana:

$\left(\mathrm{x}^{\prime}, \mathrm{y}^{\prime}\right)=$ Koordinat citra hasil koreksi geometrik

$(\mathrm{x}, \mathrm{y})$ orig $=$ Koordinat titik kontrol tanah pada bidang referensi

$\mathrm{N}=$ Jumlah GCP

Koreksi geometrik dianggap benar apabila Root Mean Square (RMS) Error $\leq 1$ piksel [6].

b. Ground Truth (cek lapangan) untuk mengumpulkan data sekaligus melakukan dokumentasi di lapangan sebagai kontrol terhadap interpretasi visual citra satelit di tahap selanjutnya.

c. Proses interpretasi citra secara visual, yaitu dengan melihat karakteristik objek berdasarkan aspek keruangan (spasial). Untuk melakukan interpretasi tutupan lumpur dari citra satelit, digunakan beberapa unsur yang terdiri atas warna, bayangan, tekstur, pola, dan asosiasi kenampakan. Kemudian hasil interpretasi visual citra satelit tadi diklasifikasikan menjadi beberapa kelas tutupan lumpur, antara lain: Air Berlumpur, Lumpur Basah, Lumpur Kering, dan Lumpur Mulai Mengering. Hasil klasifikasi tutupan lumpur tersebut kemudian digeneralisasi dengan cara digitasi. Langkah ini diambil agar nantinya proses perhitungan volume tutupan lumpur menjadi lebih singkat.

d. Selanjutnya dilakukan perhitungan volume semburan lumpur menggunakan data koordinat 3 dimensi hasil observasi lapangan menggunakan GPS Geodetik metode Kinematik. Yang terakhir adalah melakukan pemodelan 3 dimensi elevasi permukaan lumpur, agar diketahui kecenderungan arah aliran dan bentuk permukaan lumpur itu sendiri.

\section{Data dan Peralatan}

1) Data

Data yang digunakan dalam penelitian ini adalah:

1. Citra satelit Worldview-2 akuisisi bulan Agustus 2014;

2. Citra satelit Worldview-2 akuisisi bulan Juli 2015;

3. Data koordinat X, Y, dan Z di permukaan lumpur, hasil observasi lapangan menggunakan GPS Geodetik (Kinematik).

\section{2) Peralatan}

Adapun peralatan yang digunakan dalam penelitian tugas akhir ini, antara lain:

- Perangkat keras:

1. Notebook untuk pengolahan data citra satelit, perhitungan volume lumpur, visualisasi 3 dimensi elevasi permukaan lumpur, analisa data hasil pengolahan, dan penulisan laporan;

2. GPS Geodetik dengan merk Sokkia tipe GRX1 untuk melakukan observasi GPS metode kinematik guna memperoleh koordinat di permukaan lumpur dan taggul penahan; dan

3. Handphone untuk dokumentasi observasi lapangan.

- Perangkat lunak:

1. Sistem operasi Windows 10 Enterprise 64-bit;

2. ArcGIS 10.3 untuk klasifikasi tutupan permukaan lumpur, pembuatan visualisasi 3 dimensi permukaan lumpur, dan layouting peta;

3. Perangkat lunak pengolah citra untuk proses mosaicking data citra satelit resolusi tinggi; dan

4. Microsoft Office 2016 untuk penulisan laporan dan pengolahan data angka tabular perhitungan volume tutupan permukaan lumpur;

\section{HASIL DAN ANALISA}

\section{A. Klasifikasi Supervised}

Dari hasil observasi permukaan lumpur di lapangan pada bulan Juli 2015, tutupan lumpur terbagi menjadi 4 klasifikasi, antara lain adalah Air Berlumpur, Lumpur Basah, Lumpur Mulai Mengering, dan Lumpur Kering. Berikut ini adalah hasil klasifikasi tutupan lumpur:

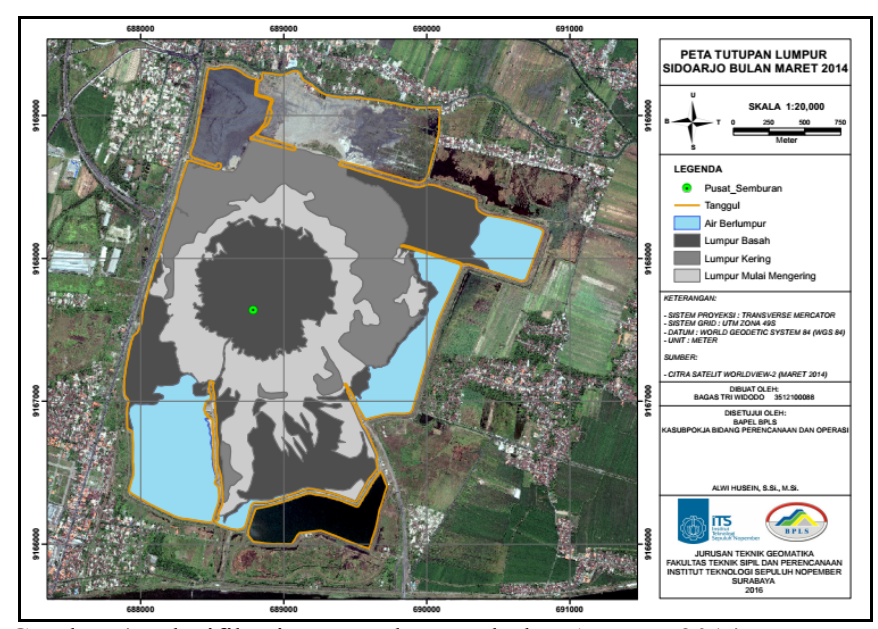

Gambar 4. Klasifikasi tutupan lumpur bulan Agustus 2014.

Dari gambar 4 dan 5, Air Berlumpur berwarna biru muda, Lumpur Basah berwarna abu-abu kehitaman, Lumpur Mulai Mengering berwarna abu-abu, dan Lumpur Kering berwarna abu-abu tua. Sedangkan titik berwarna hijau adalah pusat semburan lumpur. 


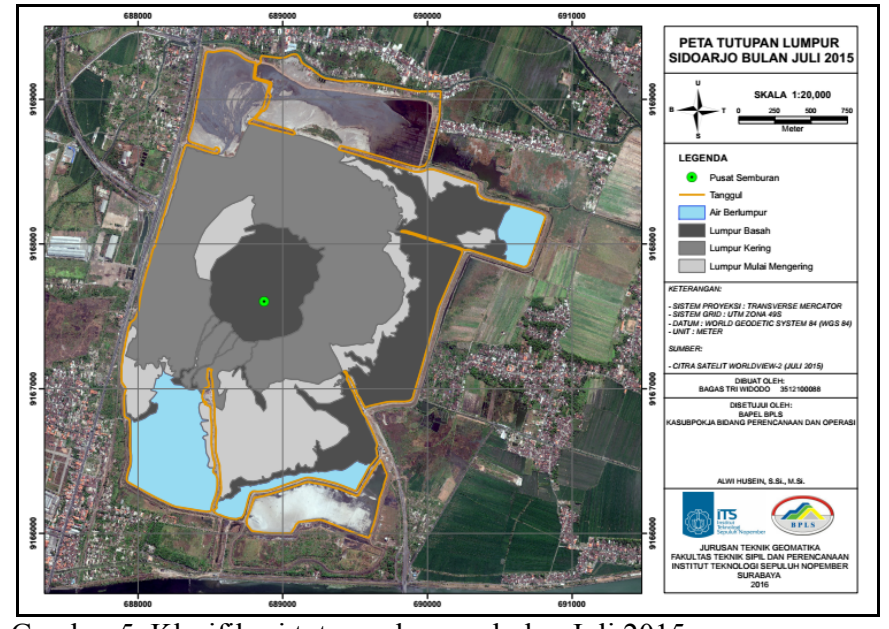

Gambar 5. Klasifikasi tutupan lumpur bulan Juli 2015.

Jika diperhatikan pada gambar 4 dan 5, lumpur basah cenderung mengarah ke bagian timur tanggul penahan lumpur. Kemudian lumpur di timur tanggul dan di sekeliling lumpur basah sudah mulai mengering, ditandai dengan meluasnya tutupan Lumpur Kering pada bulan juli 2015. Tutupan Lumpur Mulai Mengering pada bagian selatan pun meluas, yang sebelumnya dominan tutupan Lumpur Basah.

\section{B. Perhitungan Volume Tutupan Lumpur}

Untuk melakukan perhitungan volume tutupan lumpur, dibutuhkan data luasan tutupan lumpur yang sudah dibuat dan dijabarkan pada poin sebelumnya, dan data elevasi dari hasil observasi lapangan. Data elevasi tutupan lumpur didapatkan menggunakan alat GPS Geodetik dengan metode Kinematik.

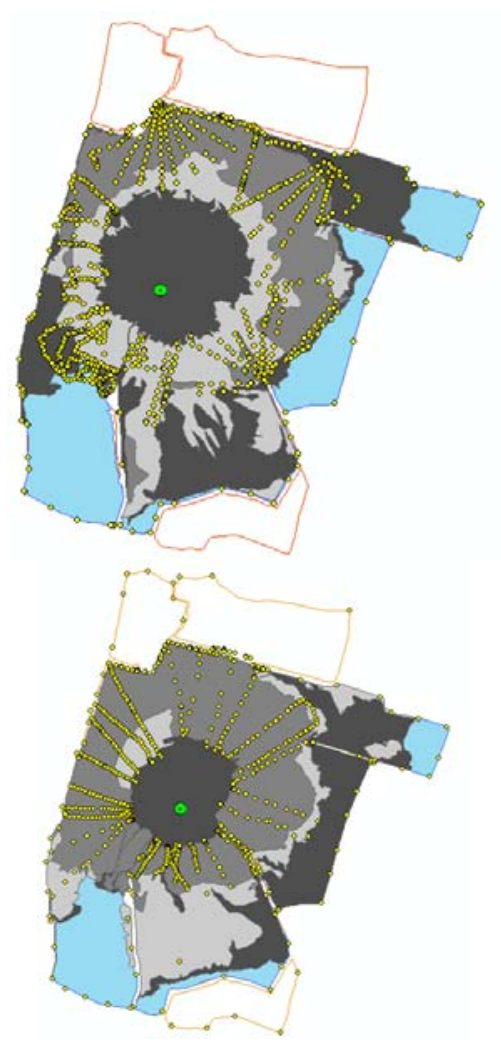

Gambar 6. Data titik pengukuran elevasi bulan Maret 2014 dan Juli 2015.
Data sampel elevasi yang telah diambil pada permukaan lumpur, selanjutnya dihitung untuk mendapatkan nilai elevasi keseluruhan di dalam tanggul utama. Semakin banyak dan merata sampel yang diambil, maka perhitungan volume yang dilakukan menjadi lebih akurat. Setelah data koordinat beserta elevasi di-overlay-kan dengan hasil klasifikasi tutupan lumpur, maka dapat dihitung volume lumpur keseluruhan berdasarkan klasifikasi tersebut

Tabel 1.

Volume tutupan lumpur bulan Maret 2014

\begin{tabular}{|c|c|c|c|}
\hline \multicolumn{4}{|c|}{ MARET 2014} \\
\hline Klasifikasi & $\begin{array}{c}\text { Elevasi } \\
\text { Rata-Rata } \\
(\mathrm{m}) \\
\end{array}$ & Luas $\left(\mathrm{m}^{2}\right)$ & Volume $\left(\mathrm{m}^{3}\right)$ \\
\hline Air Berlumpur & 7,4411 & $945.826,49$ & $7.037 .950,25$ \\
\hline Lumpur Kering & 10,8074 & $979.711,04$ & $10.588 .084,74$ \\
\hline Lumpur Basah & 9,1354 & $1.679 .201,49$ & $15.340 .213,82$ \\
\hline $\begin{array}{c}\text { Lumpur Mulai } \\
\text { Mengering }\end{array}$ & 9,2465 & $1.197 .524,23$ & $11.072 .874,55$ \\
\hline & & Total & $44.039 .123,365$ \\
\hline
\end{tabular}

Tabel 2.

Volume tutupan lumpur bulan Juli 2015

\begin{tabular}{cccc}
\hline \hline \multicolumn{4}{c}{ JULI 2015 } \\
\hline Klasifikasi & $\begin{array}{c}\text { Elevasi } \\
\text { Rata-Rata } \\
(\mathbf{m})\end{array}$ & Luas $\left.\mathbf{( m}^{\mathbf{2}}\right)$ & Volume $\left.\mathbf{( m}^{\mathbf{3}}\right)$ \\
\hline Air Berlumpur & 7,8291 & $588,234.59$ & $4.605 .361,51$ \\
Lumpur Kering & 11,5692 & $1.939 .155,96$ & $22.434 .478,24$ \\
Lumpur Basah & 9,2989 & $1.290 .761,32$ & $12.002 .633,96$ \\
$\begin{array}{c}\text { Lumpur Mulai } \\
\text { Mengering }\end{array}$ & 8,8199 & $975.563,15$ & $8.604 .405,35$ \\
\hline & & Total & $\mathbf{4 7 . 6 4 6 . 8 7 9 , 0 5 8}$ \\
\hline \hline
\end{tabular}

Dalam selang waktu 17 bulan atau 1 tahun 5 bulan, terdapat selisih volume sebesar 3.607.755,693 $\mathrm{m}^{3}$ antara bulan Maret 2014 dengan Bulan Juli 2015. Volume pada tabel 2 dan selisihnya tersebut sebenarnya bisa menjadi lebih besar jika pihak Badan Pelaksana Badan Penanggulangan Lumpur Sidoarjo tidak melakukan pemindahan/pembuangan lumpur melalui jalur pipa ke sungai porong. Volume tutupan lumpur pada bulan maret 2014 didominasi oleh tutupan lumpur basah $\left(15.340 .213,82 \mathrm{~m}^{3}\right)$. Ini mungkin terjadi disebabkan karena pada bulan tersebut telah mulai memasuki musim penghujan.

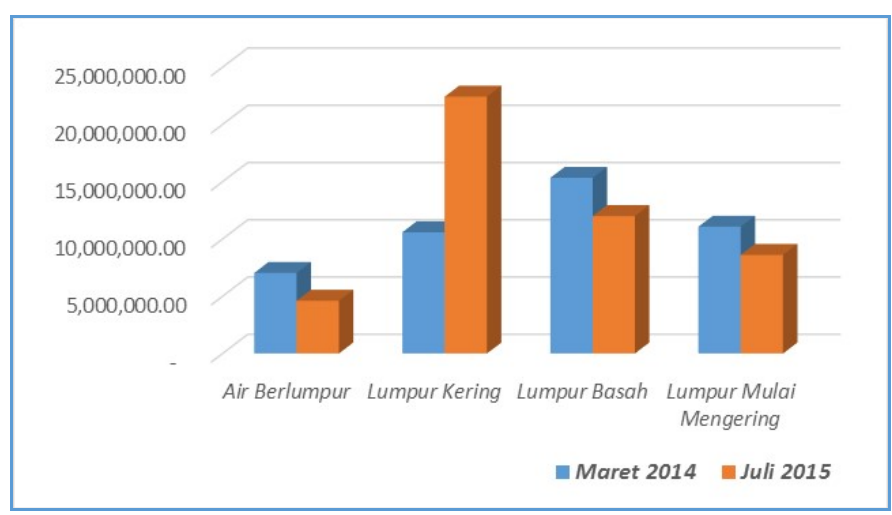

Gambar 7. Grafik volume per klasifikasi tutupan lumpur bulan Maret 2014 dan Juli 2015. 
Berbeda dengan bulan Maret 2014, pada bulan Juli 2015 justru tutupan Lumpur Kering lebih mendominasi $\left(22.434 .478,24 \mathrm{~m}^{3}\right)$. Karena pada saat penulis melakukan kegiatan ground truth / observasi lapangan, memang sudah memasuki musim kemarau, yang membuat kandungan air di dalam lumpur menjadi lebih sedikit.

\section{Visualisasi Pemodelan 3 Dimensi Permukaan Lumpur}

Pemodelan 3 dimensi ini dilakukan menggunakan fasilitas ArcScene, yang masih dalam satu konstelasi perangkat lunak ArcGIS. Tujuan melakukan pemodelan 3 dimensi adalah untuk mengetahui bentuk permukaan tutupan lumpur yang muncul sejak tanggal 29 Mei 2006 tersebut. Data yang digunakan pada pemodelan ini adalah data elevasi yang sudah dijadikan satu dalam struktur data TIN (triangulated Irregular Network) [4].

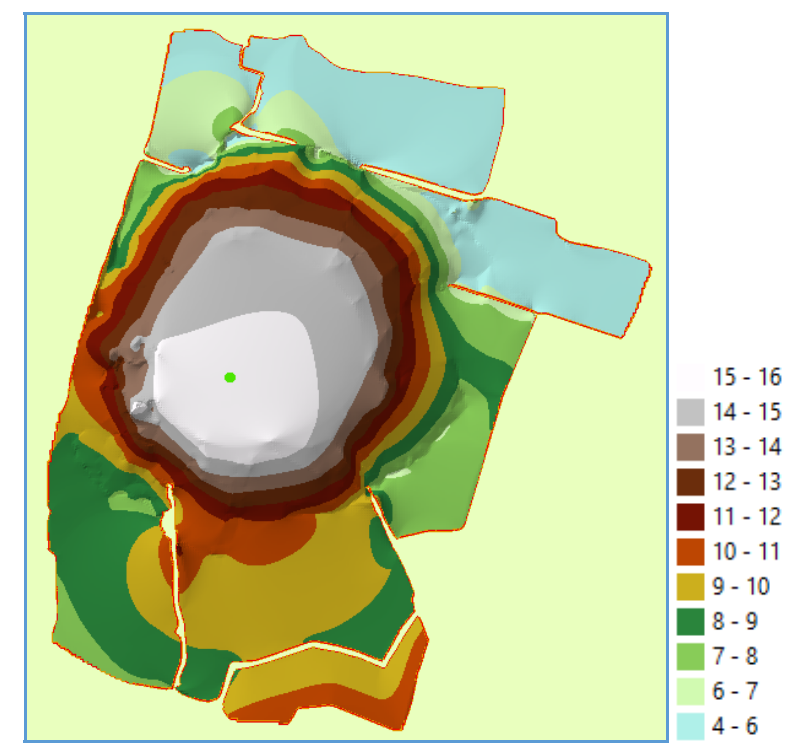

Gambar 8. TIN Elevasi permukaan lumpur bulan Maret 2014.

Struktur data TIN ini mengandung nilai elevasi permukaan lumpur, yang kemudian akan dimodelkan menjadi bentuk 3 dimensi [4]. Pada gambar 8, elevasi terendah adalah 4,38 meter yang dominan berada di sebelah utara tanggul. Tanggul sebelah utara tersebut jebol pada pertengahan tahun 2011 lalu. Dan elevasi tertingginya adalah 16,22 meter yang berada di dekat pusat semburan lumpur.

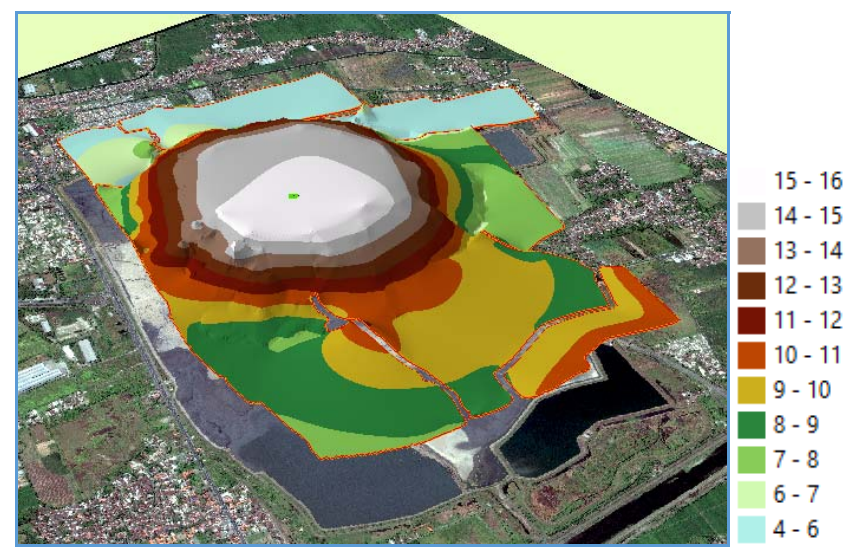

Gambar 9. Model 3 dimensi permukaan lumpur bulan Maret 2014.
Berdasarkan pemodelan elevasi permukaan lumpur pada gambar 9, elevasi permukaan lumpur bagian utara yang berdekatan dengan pusat semburan lebih rendah daripada di sebelah selatan, sehingga hal ini akan mempengaruhi arah aliran lumpur yang cenderung mengarah ke utara. Hal ini terjadi, mungkin dikarenakan oleh kondisi topografi tanah di sebelah selatan memang lebih tinggi, mengingat terdapat Gunung Penanggunan di sebelah selatan Kabupaten Sidoarjo. Atau memang hal ini terjadi dikarenakan faktor dari dalam permukaan lumpur yang sangat dinamis, sehingga membuat elevasi lumpur di sebelah selatan yang berdekatan dengan pusat semburan menjadi lebih tinggi.

Jika beralih pada gambar 10, dapat terlihat bahwa daerah di sekeliling pusat semburan tidak lagi seperti pada gambar 8 . Permukaan pada bulan Juli 2015 yang didominasi dengan tutupan lumpur kering membuat aliran lumpur basah lebih terkonsentrasi di dekat pusat semburan. Di sisi lain, ketinggian lumpur di sebelah barat, barat daya, dan selatan tanggul menjadi lebih tinggi. Jika sudah demikian, sedikit banyak ini dapat menyulitkan pihak BPLS dalam melakukan kegiatan maintenance pipa untuk mengalirkan lumpur basah ke kali porong yang berada di sebelah selatan tanggul penahan. Karena saat terjadi kendala pada jalur pipa tersebut, posisi pipa berada di bawah permukaan lumpur yang lebih tinggi.

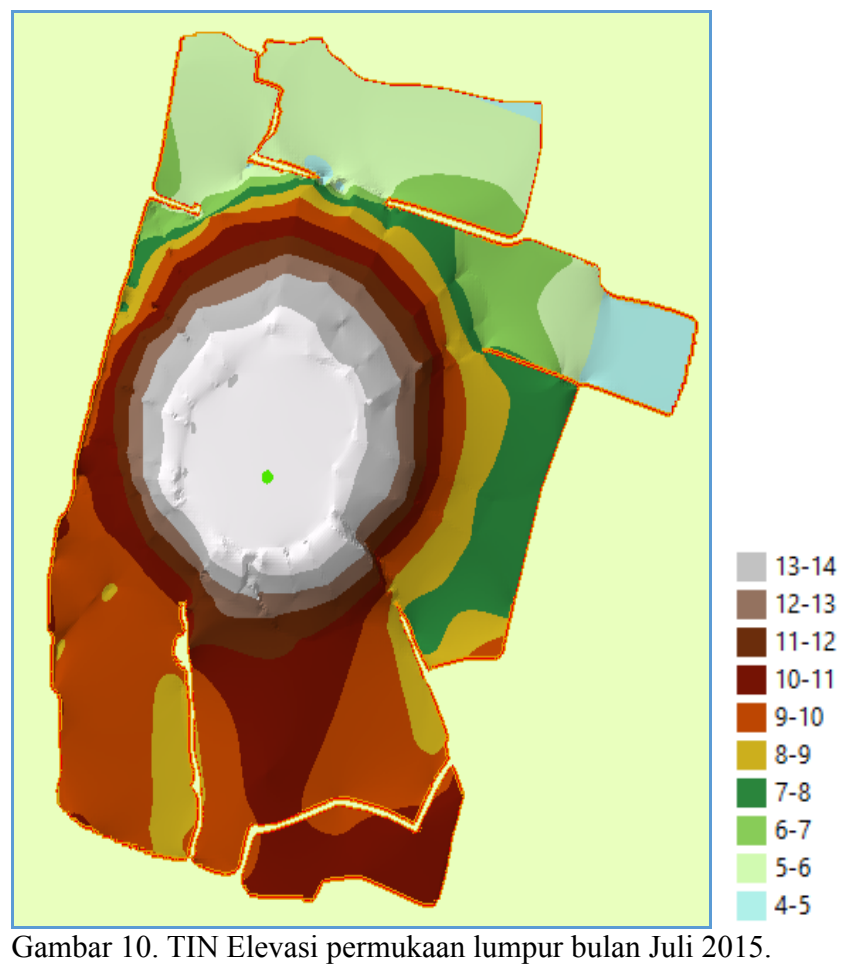

Elevasi maksimum pada permukaan lumpur bulan Juli 2015 adalah sebesar 14,67 meter (di dekat pusat semburan). 1,55 meter lebih rendah dari elevasi maksimum pada bulan Maret 2014. Seperti pada paragraf sebelumnya, hal ini terjadi dikarenakan volume lumpur basah yang terkonsentrasi di dekat pusat semburan sudah terlalu masif, sehingga struktur tanah di bawahnya tidak lagi dapat menahan beban, menyebabkan penurunan permukaan tersebut. 


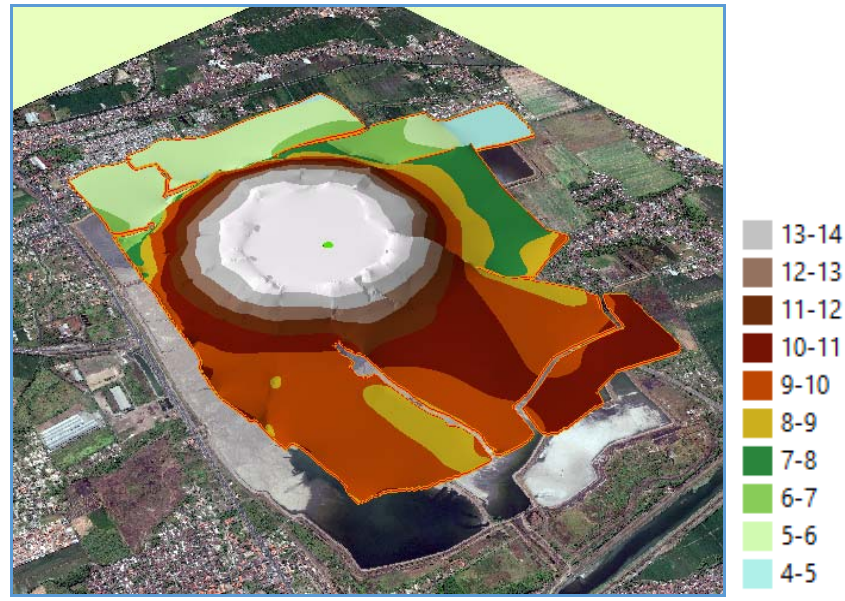

Gambar 11. Model 3 dimensi permukaan lumpur bulan Juli 2015.

Sedangkan jika dilihat dari sisi samping, bentuk permukaan lumpur di dekat pusat semburan terlihat seperti kaldera atau fitur kawah gunung lumpur. Sekali lagi, ini terjadi karena faktor musim kemaru yang membuat lumpur mengering dan keras, membuat konsentrasi lumpur basah dominan berada di dekat pusat semburan. Akibatnya, tanah yang menopang di bagian bawah tidak kuat lagi untuk menahan, sehingga mengalami sledding, dan terbentuklah fitur kaldera seperti yang ditunjukkan pada gambar 11.

\section{KESIMPULAN DAN SARAN}

Adapun beberapa hal yang bisa disimpulkan dari penelitian ini adalah :

1. Tutupan lumpur terbagi menjadi 4 klasifikasi, antara lain adalah Air Berlumpur, Lumpur Basah, Lumpur Mulai Mengering, dan Lumpur Kering. Lumpur Basah cenderung mengarah ke bagian timur dari tanggul penahan lumpur. Tutupan Lumpur Mulai Mengering pada bagian selatan pun meluas, yang sebelumnya dominan tutupan Lumpur Basah.

2. Volume total tutupan lumpur bulan Maret 2014 dan Juli 2015 adalah $44.039 .123,365 \mathrm{~m}^{3}$ dan $47.646 .879,058 \mathrm{~m}^{3}$. Terdapat selisih sebesar 3.607.755,693 $\mathrm{m}^{3}$.

3. Elevasi tertinggi permukaan lumpur pada bulan Maret 2014 adalah $16,22 \mathrm{~m}$, sedangkan elevasi terendahnya sebesar 4,38 m. Dan pada bulan Juli 2015, elevasi tertingginya sebesar 14,67 m, elevasi terendah 4,16 m.

4. Dari hasil pemodelan 3 dimensi bulan Maret 2014, didapati arah aliran lumpur cenderung ke arah utara. Pada bulan Juli 2015, lumpur basah terkonsentrasi di dekat pusat semburan, dikarenakan faktor musim kemarau yang membuat lumpur di dalam tanggul mengering dan keras. Hal ini mengakibatkan tanah di bawahnya tidak kuat menahan, dan mengalami sledding.

Berdasarkan penelitian ini, data citra satelit resolusi tinggi juga dapat dikolaborasikan dengan data pengukuran GPS untuk mencari volume permukaan, dalam hal ini permukaan lumpur Sidoarjo. Namun alangkah baiknya jika hasil perhitungan volume ini dapat di-compare dengan data volume hasil pengukuran langsung di lapangan, yang umumnya menggunakan alat Total Station. Sehingga dapat diketahui perbandingan, selisih, dan kedekatan hasil perhitungan keduanya.

Selain itu, hasil perhitungan volume dan pemodelan 3 dimensi permukaan lumpur pada penelitian ini akan lebih akurat jika dilakukan setiap bulan pada 1 tahunnya. Ini akan dapat membantu pihak BAPEL BPLS dalam melakukan langkah-langkah antisipasi jika volume lumpur telah melebihi batas ketinggian tanggul, mengingat kondisi di dalam tanggul juga sangat dipengaruhi oleh faktor musim dan cuaca.

\section{DAFTAR PUSTAKA}

[1] Abidin, H. Z. (1995). Penentuan Posisi Dengan GPS dan Aplikasinya. Jakarta: Pradnya Paramita.

[2] Akbari, A. M., \& Hariyanto, T. (2012). PERHITUNGAN VOLUME SEMBURAN DAN SEBARAN LUMPUR SIDOARJO DENGAN CITRA IKONOS BULAN JUNI, AGUSTUS, OKTOBER 2011. Surabaya: Teknik Geomatika ITS.

[3] Evan. 2014. Tanggul Lapindo, dari Jebol ke Jebol, http://nasional.tempo.co/read/news/2014/09/11/058606020/tanggullapindo-dari-jebol-ke-jebol, diakses tanggal 5 Mei 2016.

[4] Kreveld, M. v. 1997. Algorithms for Triangulated Terrains. Dept. of Computer Science, Utrecht University, The Netherlands.

[5] Lo, C.P., Yeung, A.K.W., 2002. Concepts and Techniques of Geographic Information Systems. Prentice Hall, Upper Saddle River, New Jersey.

[6] Rianelly, Prenita S., 2011. Analisa Perubahan Tata Guna Lahan Wilayah Surabaya Barat Menggunakan Citra Satelit Quickbird Tahun 2003 Dan 2009. Surabaya: Tugas Akhir Program Studi Teknik Geomatika ITS. 